\title{
Acute Imbalance and Constitutional Syndrome: The Answer May Lie on the Front of the Head
}

JAVIER RIANCHO, MD, Service of Neurology; JON INFANTE, PhD, Service of Neurology; CARMEN GONZÁLEZ-VELA, MD, Pathology; JOSE MANUEL CARRIL, PhD, Nuclear Medicine; JOSÉ BERCIAN, PhD, Service of Neurology; and ISABEL MARTÍNEZ-RODRIGUEZ, MD, Nuclear Medicine, University Hospital Marqués de Valdecilla (IFIMAV), University of Cantabria, and Centro de Investigación Biomédica en Red de Enfermedades Neurodegenerativas (CIBERNED), Santander, Spain. Address correspondence to Dr. J. Riancho, Service of Neurology, Hospital Universitario Marqués de Valdecilla, Av Valdecilla s/n 39011, Santander, Spain. E-mail: jariancho@humv.es. J Rheumatol 2014;41:143-4; doi:10.3899/jrheum.130644

Ischemic stroke is currently one of the most important diseases because of its frequency, mortality, and longterm sequelae. Even though high blood pressure and other cardiovascular disorders are the most frequent etiologies, a small percentage of cases are related to uncommon diseases. We describe a patient with an ischemic stroke secondary to large vessel vasculitis.

A 79-year-old man with an unremarkable medical history except for mild hypertension presented unable to walk. The neurological examination showed dysarthria and severe right-side ataxia. A multimodal brain computed tomography (CT) scan showed an ischemic area on the right cerebellar hemisphere secondary to thrombosis of both vertebral arteries. Laboratory analyses revealed an erythrocyte sedimentation rate (ESR) of $101 \mathrm{~mm} / \mathrm{h}$, a C-reactive protein (CRP) of $6.7 \mathrm{mg} / \mathrm{dl}$, and a mild normocytic anemia. When questioned, he admitted malaise, fever, and weight loss for the past 2 months. He denied headache, visual defects, or any other systemic symptom. Physical examination demonstrated painless enlarged temporal arteries (Figure 1A). Giant cell arteritis (GCA) was suspected and high-dose steroid therapy was initiated (methylprednisolone $1 \mathrm{~g}$ /day for 3 days, followed by $60 \mathrm{mg} /$ day prednisone). An F-18 fluorodeoxyglucose positron emission tomography (FDG-PET) scan showed intense FDG uptake along the vertebral arteries (Figure 1B). The temporal artery biopsy confirmed the diagnosis. After 2 weeks the patient was able to walk. ESR and CRP fell into normal ranges. He was discharged on prednisone $60 \mathrm{mg} /$ day, statins, aspirin, calcium, and bisphosphonates. Two months later, a new PET/CT showed resolution of previous FDG uptake at vertebral arteries (Figure C).
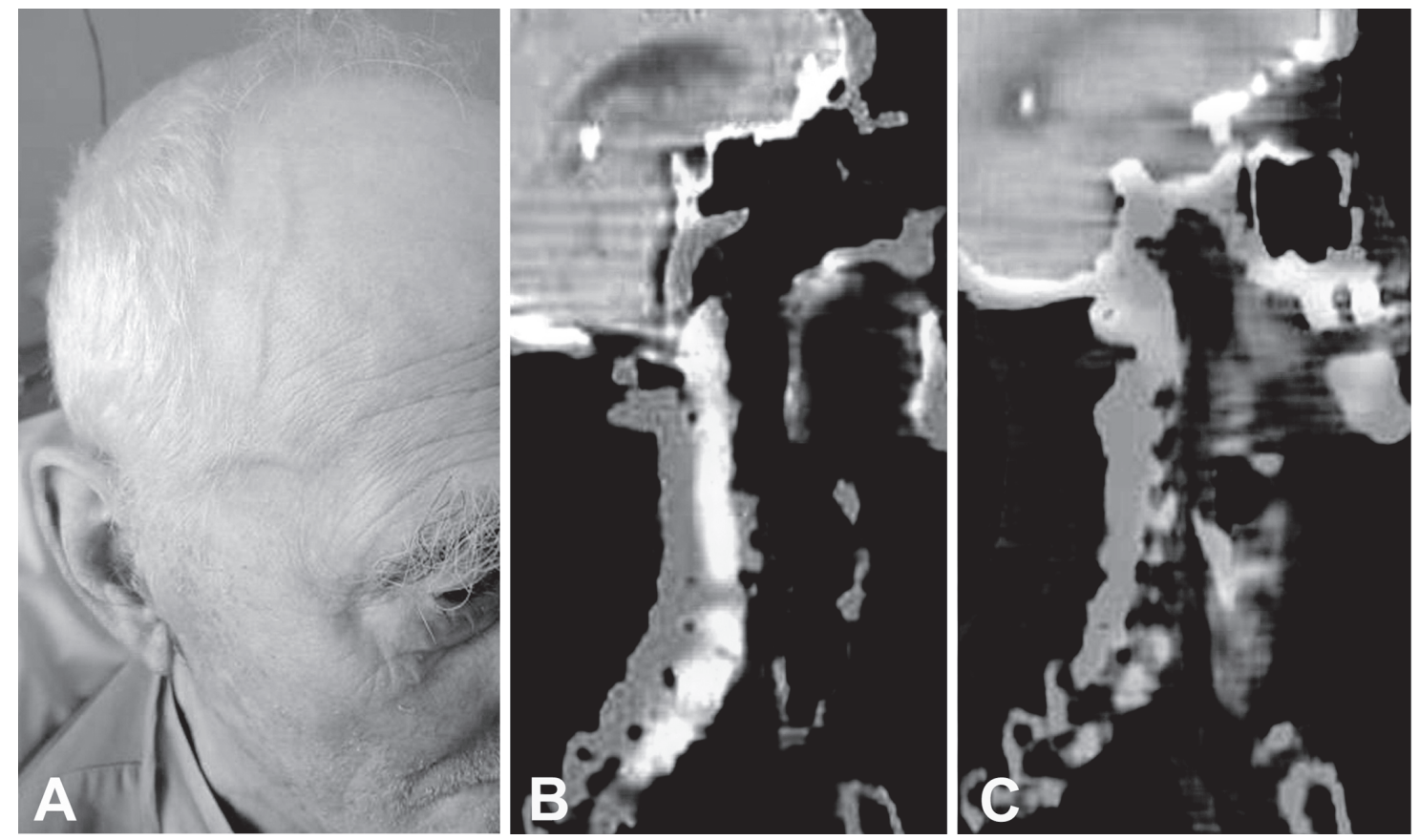

Figure 1. A. Enlarged temporal arteries. B. Axial positron emission tomography-computed tomography (PET-CT) showing intense F-18 fluorodeoxyglucose (FDG) uptake along the vertebral arteries. C. Control PET-CT showing resolution of the previous abnormal uptake at the vertebral vessels.

Personal non-commercial use only. The Journal of Rheumatology Copyright @ 2014. All rights reserved. 
Ischemic stroke is a very rare manifestation of GCA ( $2.8 \%$ of patients). As in our patient, most series vertebral arteries are affected in $>87 \%$ of cases ${ }^{1,2,3}$. As our case illustrates, owing to the increased metabolism in inflammatory disorders, FDG-PET/CT may be useful for diagnosis and followup even when temporal artery biopsy is negative $e^{4,5}$.

\section{REFERENCES}

1. Gonzalez-Gay MA, Vazquez-Rodriguez TR, Gomez-Acebo I, Pego-Reigosa R, Lopez-Diaz MJ, Vazquez-Trinanes MC, et al. Strokes at time of disease diagnosis in a series of 287 patients with biopsy-proven giant cell arteritis. Medicine 2009;88:227-35.

2. Salvarani C, Della BC, Cimino L, Macchioni P, Formisano D, Bajocchi G, et al. Risk factors for severe cranial ischaemic events in an Italian population-based cohort of patients with giant cell arteritis. Rheumatology 2009;48:250-3.
3. Pego-Reigosa R, Garcia-Porrua C, Pineiro A, Dierssen T, Llorca J, Gonzalez-Gay MA. Predictors of cerebrovascular accidents in giant cell arteritis in a defined population. Clin Exp Rheumatol 2004;22:S13-7.

4. Blockmans D, De Ceuninck L, Vanderschueren S, Knockaert D, Mortelmans L, Bobbaers H. Repetitive 18F-fluorodeoxyglucose positron emission tomography in giant cell arteritis: a prospective study of 35 patients. Arthritis Rheum 2006;55:131-7.

5. Martinez-Rodriguez I, Castillo-Matos R, Rubio-Vassallo A, Ortega-Nava F, Martinez-Amador NA, Carril JM. Diagnosis and assessment of the treatment response in a case of giant cell arteritis using (18)F-FDG PET/CT. Rev Esp Med Nucl Imagen Mol 2012;31:233-5. 